\title{
DEFICIENCIES IN TECHNICAL AND VOCATIONAL EDUCATION AND TRAINING LECTURER INVOLVEMENT QUALIFICATIONS AND ITS IMPLICATIONS IN THE DEVELOPMENT OF WORK RELATED SKILLS
}

\author{
A. van der Bijl \\ Teacher Professional Development \\ Cape Peninsula University of Technology \\ Cape Town, South Africa \\ e-mail: vanderbijla@cput.ac.za
}

\section{J. Oosthuizen}

NATED Trimester Evening Classes

West Coast College

Vredenburg, South Africa

e-mail: loosthuizen8@gmail.com

\section{ABSTRACT}

Technical Vocational Education and Training (TVET) lecturers play an important role in providing a competent workforce that can contribute to economic development. To develop a competent and employable workforce TVET college lecturers need a combination of qualifications and experience that provides them with workplace-related competency, teaching or pedagogic competency and qualifications both for which they prepare their students and which are regarded as necessary for learning to be properly facilitated. Research has shown that few South African TVET college lecturers have adequate academic, workplace and teaching qualifications. This article reports the deficiencies in qualifications and experience of lecturers at TVET colleges in South Africa and the implications of the identified deficiencies. While a substantial number of lecturers had academic qualifications, clear deficiencies were found in workplace related qualifications and experience, as well as in teaching qualifications.

Keywords: academic qualifications, workplace qualifications, teaching qualifications, TVET colleges

\section{INTRODUCTION}

Internationally, technical vocational education and training (TVET) lecturers are required to work in a wide range of contexts. They have to deal with specialist service providers, provide career advice and work placement, manage their administrative functions, translate training packages into training programmes, and assess the outcomes of that training (Guthrie 2010, 11; Smith and Grace 2014, 204; Lloyd 2008, 175). They also need to be able to develop teaching and learning resources for students and make appropriate use of available learning technologies 
(Guthrie 2010, 11).

Professionally qualified lecturers in South Africa, according to the policy on professional qualifications for lecturers in technical and vocational education and training (South Africa 2013,40 ), should have a sound knowledge base of their subject of specialisation, and must be professionally qualified to manage teaching and learning environments effectively. Lecturers should also be familiar with the workplace demands of business and industry and be able to use the subjects they teach to help equip students for the workplace.

Professionally qualified TVET lecturers required to have expertise in at least three domains, namely academic or subject matter knowledge, pedagogy, and workplace qualifications and experience (Lloyd 2008, 175; McBride, Papier and Needham 2009, 7; Smith and Grace 2014, 204). In reality, however, few TVET college lecturers have expertise in all three domains. A number of studies have analysed the situation in South Africa, but were limited to the acquisition of regional data.

A research project conducted at TVET colleges between 2015 and 2016 provided an opportunity for a national quantitative analysis of TVET college lecturer qualifications, as well as experience in the classroom and the workplace from which they have gained their expertise. The analysis confirms findings on regional and industry-based studies and points to the need for the development of in-service training leading to formal qualifications. The analysis also points to the need for workplace based training.

\section{LECTURER QUALIFICATIONS AND TRAINING}

Technical vocational education and training (TVET) is one of the elements of the South African education and training system. It has existed, according to Blom $(2016,2)$ in "many different guises" including technical colleges and further education and training colleges. Over the course of the twentieth century TVET has been devised as an alternative to university education, a place for the poor, indigent and the disabled. The apartheid government used TVET as a tool for the reproduction of its labour policies (Van der Bijl and Lawrence 2016, 342-344).

TVET colleges, Blom $(2016,2)$ argues, have "been encouraged to expand rapidly, especially in response to the needs of those students who are not eligible for university education", particularly since the amalgamation of technical college into multi campus institutions in 2006 and the introduction of a national vocational certificate system a year later. The state's focus on TVET has included an argument in favour of a sector specific lecturer qualifications system (South Africa 2008) and its promulgation in 2013 (South Africa 2013).

It is argued (Bialobrzeska and Allais 2005, 15) that TVET involves three types knowledge: 
- $\quad$ Theoretical knowledge

- Disciplinary knowledge

- $\quad$ Practical or workplace knowledge.

Theoretical and disciplinary knowledge are shared with other education sectors. Practical or workplace knowledge, which includes learning for and in the workplace, is specific to the TVET sector.

TVET colleges, in general, and TVET college lecturers, in particular, have been criticised for not living up to the expectations set for it. A little less than a decade ago it was described as "... the subsystem that is the most fragile as a result of the incomplete transitions it has experienced in recent years" (South Africa 2010,9). Since then the state has invested in TVET colleges but questions on lecturer deficiencies remain.

\section{Deficiencies in of TVET lecturer qualifications}

The lecturer deficiency was noted in the Green Paper on Education and Training (South Africa 2012). The Green Paper noted that lecturers in the technical fields are largely recruited from industry. As a result, the Green Paper noted, many have workplace experience and knowledge, but little pedagogical training (South Africa 2012, 24).

TVET college lectures deficiencies are not limited to a lack of pedagogic training. A study of lecturers in the Western Cape Province in 2009 (McBride et al. 2009), found that only 6 per cent of TVET lecturers had expertise in all three domains, namely an academic qualification as well as a teaching qualification and a workplace qualification or experience. More than 90 per cent of the lecturers who participated in the study did not have the desired combination of academic, teaching and workplace qualifications (McBride et al. 2009, 8).

The situation has not improved significantly since 2009. In 2016 Wedekind $(2016,22)$ noted that a significant number of lecturers need to undertake relevant studies to upgrade their qualifications. A year earlier an argument was noted that substantial component of academic staff within the South African TVET college system work without a professional teaching qualification that meets the national minimum requirements (Van der Bij1 2015, 2). A study conducted in the North-West province found that 5 per cent of lecturers only had certificates as their highest qualification. A total of 47 per cent of lecturers had a diploma while 36 per cent of the lecturers that participated in the study had a degree (Manyau 2015, 60). Earlier research in the Western Cape found that 50 per cent of lecturers had an academic qualification. Eleven per cent of these lecturers only had an academic qualification without a teaching qualification 
or work experience, while 29 per cent had a teaching qualification with no work experience or qualifications in industry (McBride et al. 2009, 8).

In the North-West Province 78 per cent of lecturers who participated in a study by Manyau (2015) indicated no teaching qualification. A total of 11 per cent of these lecturers had a diploma in education, while 4.4 per cent had an Advanced Certificate in Education or a Postgraduate Certificate in Education. It was apparent that most lecturers had problems with their teaching skills, as 50 per cent of the participating lecturers needed training in teaching strategies (Manyau 2015, 62-70). Most of these need further development in their teaching skills such as facilitation skills, assessment and moderation (Manyau 2015, 75). Again, in contrast, McBride et al. (2009) found that 65 per cent of lecturers had a teaching qualification. Of these lecturers, 17 per cent only had a teaching qualification without an academic qualification or workplace qualifications and experience. A total of 29 per cent of the lecturers also had an academic qualification, while only 12 per cent had a teaching qualification with workplace qualifications and experience (McBride et al. 2009, 8).

Manyau $(2015,75)$ contends that TVET college lecturers need technical and industryrelated exposure and skills. Manyau $(2015,75)$ established that 2.1 per cent of TVET lecturers had less than one year of work or industry experience, while 49.5 per cent had between two and four years of work or industry experience. Lecturers with five to seven years of work experience made up 25.3 per cent, and 16.5 per cent had eight to ten years of work experience. A total of 51.6 per cent of lecturers had less than five years of work experience or exposure to industry (Manyau 2015, 63). In McBride et al.'s (2009, 8) study 37 per cent of lecturers had workplace qualifications and experience. A total of 14 per cent of these lecturers only had a workplace qualification without an academic or teaching qualification, while 4 per cent also had an academic qualification and 12 per cent had a workplace qualification with a teaching qualification (McBride et al. 2009, 8).

A significant number of lecturers have therefore entered, and continue to enter, the South African TVET college sector without an official teaching qualification. The absence of a formal teaching qualification for lecturers implies that college lecturers have to develop their teaching competencies elsewhere (Van der Bij1 2015, 4-5).

\section{Interventions to improve lecturer competence}

The department of higher education and training has introduced a policy framework for qualifications for TVET college lecturers (South Africa 2013) but, to date, no universities have implemented programmes included in the policy framework. As a result, the development of practicing lecturer missing competences are left to in-service training, guidance received from 
colleagues and learning through experience.

The availability of training programmes to facilitate new knowledge with TVET lecturers, as well as curriculum training, technical skills training and career development and mentorship, however, seems to be sporadic and even absent at times. Manyau's $(2015,65)$ research has shown that 59 per cent of lecturers disagreed with the availability of developmental programmes. The majority of TVET lecturers had not participated in training for more than two years (Manyau 2015, 65).

When asked whether the training they received was relevant and helpful to their teaching area, more than 64 per cent of the TVET lecturers responded negatively, indicating that the training was neither relevant nor helpful to their teaching area. Furthermore, over 61 per cent of the lecturers complained that they do not get any financial support when they enrol at other institutions to develop their teaching skills (Manyau 2015, 72). This is against a background where responsible higher education managers are expected to formulate workplace skills plans that include the job analysis process, skills auditing, prioritisation, designing skills programmes, and implementing and evaluating employees training (Manyau 2015, 82).

The skills development process is also not well coordinated. In certain instances managers are still newly appointed and in other cases they have not yet implemented skills development programmes (Manyau 2015, 76). Informal learning is therefore often used to develop the teaching competency of unqualified lecturers employed by TVET colleges. These lecturers depend on both formal and informal mentoring programmes and coaching by supervisors, peers and themselves to develop their competency as educators (Van der Bij1 2015, 2).

\section{Mentoring as short-term solution to deficiencies in TVET lecturer qualifications}

Mentoring is a developmental process that occurs between individuals or between groups. While some see mentoring as a path to competency development, others regard it as a route for social transformation (Van der Bij1 2015, 15). Mentoring can thus be applied at different levels of an institution, ranging from formal programmes to self-reflection and self-monitoring. Mentoring, on a professional level, integrates a person into the profession, and on a broader level integrates a person into a specific socio-cognitive paradigm (Van der Bij1 2015, 50).

Employee engagement programmes, which include mentoring, depend on recognition, feedback, attitudes towards direct managers, commitment to the institution, and socialisation into the new work environment affect the integration of a new lecturer (Mmako and Schultz 2016, 159). Obstacles to mentoring Van der Bijl $(2015,8)$ explains, include lack of formal mentoring programmes and broadness in definition. New lecturers are mentored in the posts they fill but mentors are not formally allocated and no reciprocal or systematic mentoring takes 
place (Van der Bij1 2015, 8). Mmako and Schultz $(2016,154)$ maintain that managers should hold regular one-on-one meetings with lecturers, showing genuine care and concern for them, and that constructive, specific feedback should be given to lecturers during their development.

No evidence could be found of the structure of mentoring in South African TVET colleges and it might well be that no clear formal mentoring practices have evolved, been recognised or developed in South African TVET colleges (Van der Bij1 2015, 50, 131). The absence of a formal mentoring programme Van der Bijl $(2015,132)$ found, was not seen as a shortcoming and when lecturers were interviewed, they were of the opinion that they should take responsibility for their own mentoring. Commonly, lecturers in TVET colleges have to be their own mentors (Van der Bij1 2015, 132).

Mentoring programmes could serve as a vehicle for passing on subject knowledge and best teaching practices (Van der Bij1 2015, ii). In addition, the integration of knowledge gained through an academic qualification, workplace qualification or experience and teaching qualification will be facilitated in the existence of a formal, structured mentoring programme. In order to determine the level of qualifications, and how lecturer qualifications and skills were supplemented, we conducted a survey nationally in South Africa in 2016.

While the studies done by McBride and Mmako indicate shortcomings in TVET lecturer qualifications and Van der Bijl's study indicates strategies used by some lecturers in the Western Cape, there is a dearth of recent information on how ostensibly unqualified and underqualified lecturers develop their classroom-related skills.

\section{RESEARCH DESIGN AND METHODOLOGY}

In 2015 and 2016 focus group exercises were conducted at 18 TVET colleges as part of the EDTP SETA/CPUT Research Chair for WIL and RPL. At the end of each focus group discussion a questionnaire was circulated with a request for individual, confidential responses. The survey produced quantitative data which provided a generalisable overview on the views TVET lecturers had about their academic qualifications, teaching qualifications, occupational qualifications and their experience at TVET colleges. The research instrument was a selfconstructed closed-ended survey questionnaire which used a five-point Likert scale as measurement. The aim of the questionnaire was to determine the level of academic qualifications, teaching qualifications, workplace qualifications and experience of TVET college lecturers in South Africa.

The study population consisted of 50 TVET colleges $(\mathrm{N}=50)$ across South Africa, from which nine $(\mathrm{n}=16)$ were selected through random sampling. A total of 249 lecturers were invited to complete the survey questionnaire, which was administered from February to September 
2016. The Department of Higher Education and Training, as well as senior management of each college involved, gave permission for research to be conducted. Participation of lecturers was anonymous and confidentiality assured. Completion of the survey was voluntary.

The analysis of the completed questionnaires was done by reading the data into the SPSS statistical program for processing. Both descriptive (standard deviation and mean) and inferential (effect sizes and Cronbach's alpha) statistical techniques were utilised in the analysis of the data.

Lecturing and management staff totalling 27 individuals were asked to complete the survey and provide feedback on the relevance, clarity and suitability of the survey questions. Factor analysis was the statistical technique used to determine construct validity (Pietersen and Maree 2014, 216-218). Face validity was enhanced by scrutinising having the content of the survey questionnaire evaluated by the facilitators involved, prior to its implementation. Face validity refers to the extent that an instrument looks valid. Criterion validity determines whether an instrument tests what it is supposed to measure (Pietersen and Maree 2014, 217).

There was a high degree of similarity among items tested since they were measuring a common construct. The measure of similarity was an indication of the internal reliability of the instrument. The internal reliability of an instrument was measured through the Cronbach's alpha coefficient (Pietersen and Maree 2014, 215-216). The Cronbach's alpha coefficient for this study was $0.85(\alpha=0.85)$.

\section{ACADEMIC QUALIFICATIONS, TEACHING QUALIFICATIONS, WORKPLACE QUALIFICATIONS AND EXPERIENCE OF TVET LECTURERS}

\section{Demographics}

A total of 249 TVET lecturers working at 16 different TVET colleges in South Africa responded to the survey questionnaire in 2017. The age distribution of lecturers who participated is displayed in Table 1.

At the time of the survey 37 of the 249 participating lecturers were between the ages of 20 and 30 . The majority of lecturers $(n=94)$ were between 30 and 40 years of age, while 82 lecturers were between 40 and 50 years old $(n=82)$. The smallest number of lecturers $(n=17)$ were in the age group 50 to 60 . A total of 70 per cent of TVET college lecturers therefore fell in the age group of 30 to 50 at the time of the survey. TVET colleges therefore do not appear to be threatened by an aging workforce that may retire in the near future.

Table 1: Age distribution of participating TVET lecturers 


\begin{tabular}{|c|c|c|}
\hline Age & Number of lecturers & Percentage \\
\hline $20-30$ & 37 & 14.9 \\
\hline $30-40$ & 94 & 37.8 \\
\hline $40-50$ & 82 & 32.9 \\
\hline $50-60$ & 19 & 7.6 \\
\hline Missing & 17 & 6.8 \\
\hline Total & 249 & 100 \\
\hline
\end{tabular}

The gender distribution of TVET lecturers who answered the survey questionnaire are displayed in Table 2.

Table 2: Gender distribution of participating TVET lecturers

\begin{tabular}{|l|c|c|}
\hline Gender & Number of lecturers & Percentage \\
\hline Male & 123 & 49.4 \\
\hline Female & 124 & 49.8 \\
\hline Missing & 2 & 0.8 \\
\hline Total & 249 & 100 \\
\hline
\end{tabular}

The number of male lecturers $(n=123)$ who participated in the survey compared well to the number of female lecturers $(\mathrm{n}=124)$. The gender distribution indicates a fair amount of gender equality regarding employment of lecturers.

The qualifications of lecturers who completed the survey are displayed in Table 3.

\section{Qualifications}

Table 3: Qualifications of participating TVET lecturers

\begin{tabular}{|l|c|c|}
\hline Qualifications & Number of lecturers & Percentage \\
\hline Certificate & 17 & 6.8 \\
\hline Artisan & 24 & 9.6 \\
\hline Diploma & 88 & 35.3 \\
\hline Degree & 89 & 35.7 \\
\hline Artisan with diploma or degree & 1 & 0.4 \\
\hline Missing & 30 & 12 \\
\hline Total & 249 & 100 \\
\hline
\end{tabular}

Lecturers who were in possession of a certificate $(n=17)$ represented 6.8 per cent of the population at the time. If lecturers at TVET colleges are only in possession of a certificate it raises concerns over the qualifications of lecturers teaching at these colleges. Manyau's (2015, 60) research indicated that 5 per cent of lecturers had certificates. Lecturers who only have a certificate qualification may need to further their studies in order to improve their subject 
knowledge.

Only 9.6 per cent of lecturers who completed the survey were artisans $(n=24)$. Only one lecturer $(n=1)$ was an artisan in possession of diploma or degree, which indicates a lack of academic and teaching qualifications among lecturers who are qualified artisans. McBride et al.'s $(2009,8)$ research has shown that 37 per cent of lecturers had workplace qualifications, while only 6 per cent had academic, workplace and teaching qualifications. Lecturers without workplace qualifications may need access to opportunities to qualify as artisans. Qualifying as artisans might significantly improve lecturers' understanding of application of theory and enable them to prepare students more effectively for the workplace.

Of lecturers who completed this survey, 35.3 per cent were in possession of a diploma $(n=88)$. Lecturers who had a degree $(n=89)$ represented 35.7 per cent of those lecturers who completed the survey. Therefore a large contingency of lecturers employed by TVET colleges had a theoretical qualification, which indicates substantial knowledge of subject matter. In Manyau's $(2015,60)$ research 47 per cent of the lecturers had a diploma and 36 per cent had a degree. Earlier McBride et al. $(2009,8)$ found that 50 per cent of lecturers had an academic qualification.

From the data collected it is clearly evident that it is necessary for lecturers to upgrade their academic qualifications. as subject knowledge gained through academic qualifications is valuable as it adds quality to the teaching and learning process. Academic qualifications not only have the potential to improve classroom practice it enhances social standing, both of individual lecturers and the sector compared to their better qualified counterparts employed in schooling. For young lecturers employment at TVET colleges represent a step in an academic career (Van der Bij1 2015, 94), a career marked by qualification progression.

\section{Fields of work}

The field of work of lecturers who completed the survey is displayed in Table 4.

Table 4: Field of work of participating lecturers

\begin{tabular}{|l|c|c|}
\hline Field of work & Number of lecturers & Percentage \\
\hline Engineering & 89 & 35.7 \\
\hline General Business Management & 42 & 16.9 \\
\hline Financial Management & 8 & 3.2 \\
\hline Hospitality & 8 & 3.2 \\
\hline Tourism & 11 & 4.4 \\
\hline Education & 46 & 18.5 \\
\hline Transport and Logistics & 12 & 4.8 \\
\hline Project Management & 1 & 0.4 \\
\hline
\end{tabular}




\begin{tabular}{|l|c|c|}
\hline Field of work & Number of lecturers & Percentage \\
\hline Work-integrated Learning & 4 & 1.6 \\
\hline Office Administration & 13 & 5.2 \\
\hline Agriculture & 6 & 2.4 \\
\hline Missing & 9 & 3.6 \\
\hline Total & 249 & 100 \\
\hline
\end{tabular}

Most of the lecturers who completed the survey were from the engineering field, followed by general business management and teaching. Lecturers in the engineering field $(n=89)$ who completed the survey represented 35.7 per cent of lecturers, followed by lecturers from the education field $(n=46)$, who constituted 18.5 per cent of the population. Lecturers in the general business management field $(n=42)$ represented 16.9 per cent of the participating lecturers.

A comparison between lecturer qualifications in Table 3 with the field of work of lecturers in Table 4 shows certain imbalances. Of the 89 lecturers working in the engineering field only 24 are qualified artisans, which is 27 per cent of engineering lecturers. TVET colleges are focussed on the training students to acquire workplace qualifications (Sheahan 1982, 23). According to the policy on professional qualifications for lecturers in technical and vocational education and training (South Africa 2013,7) the task of training students to acquire workplace qualifications requires lecturers who have workplace qualifications, or who are qualified artisans.

Given that only 24 of 89 lecturers in the engineering field are qualified artisans a shortage of appropriate workplace qualifications is clear. This shortage indicates a need for TVET colleges to provide opportunities for lecturers without workplace qualifications to receive training to qualify as artisans.

The proportion of lecturers from the "education" field of work $(n=46)$ indicated a representation of 18 per cent of lecturers who transferred from employment in primary and secondary schools to TVET colleges. Earlier research by McBride et al. $(2009,8)$ has shown, similarly, that 17 per cent of lecturers only had teaching qualifications without academic or occupational qualifications.

Lecturers who have moved into TVET colleges from the school sector generally have no occupational qualifications or experience and may therefore not understand how to prepare students for employment in the workplace or industry. Furthermore, lecturers who came from schools may lack an understanding of how industry works and the importance maintaining open relationships with industry. Exposing lecturers to the workplace or industry is likely to improve and update lecturer skills and knowledge by exposing them to technological innovations (Arfo $2015,106)$ and recent developments. A study of lecturer workplace experiences (Van der Bijl and Taylor 2016, 106) that lecturer experiences of work placements "were largely positive and 
useful".

\section{Workplace experience}

The workplace experience of the participating lecturers is displayed in Table 5.

Table 5: Industry experience of participating TVET lecturers

\begin{tabular}{|l|c|c|}
\hline Workplace experience & Number of lecturers & Percentage \\
\hline Less than 5 years & 130 & 52.2 \\
\hline $6-10$ years & 37 & 14.9 \\
\hline $11-15$ years & 15 & 6.0 \\
\hline 16 years and more & 10 & 4 \\
\hline Missing & 57 & 22.9 \\
\hline Total & $\mathbf{2 4 9}$ & $\mathbf{1 0 0}$ \\
\hline
\end{tabular}

The largest proportion of lecturers who completed the survey had less than five years' workplace experience in industry $(n=130)$. Lecturers with six to ten years' workplace experience $(n=37)$ represented 14.9 per cent of lecturers who completed the survey. Lecturers with 11 to 15 years' workplace experience $(n=15)$ represented 6 per cent of lecturers who completed the survey. Earlier McBride et al. $(2009,8)$ found that 37 per cent of lecturers had workplace experience while Manyau $(2015,63)$ found that 49.5 per cent of lecturers had two to four years' teaching and working experience.

Clearly therefore, many lecturers employed at TVET colleges lack experience in industry. As TVET colleges are primarily concerned with preparing students for the workplace, lecturers who lack workplace experience may not be able to prepare students effectively or link theory to practice. These lecturers may also find it difficult to maintain relationships with workplaces in industry.

Industry experience, even short time periodic experience potentially has advantages for TVET colleges, lecturers and students. As lecturers who were involved in workplace experiences noted:

"Two notable factors commonly expressed were, first, the need to develop long-term relationships between colleges and employers, on the one hand, and between lecturers and their counterparts on the other. The second factor was related to the need to develop mutual trust, once again at institutional and individual levels. Both lecturers and managers noted that trust would be the result of the development of successful long-term working relationships."

\section{INITIAL EDUCATION AND TRAINING, AND PROFESSIONAL DEVELOPMENT}

Lecturers who completed the survey had to indicate how they gained subject content knowledge, teaching skills, assessment skills and work experience using a scale of zero (never) 
to four (mostly). The statistical outcomes of this section, arranged according to ranking order, are reflected in Table 6 .

Table 6: Education and training of participating TVET college lecturers

\begin{tabular}{|c|c|c|c|}
\hline Rank & Education and training of TVET lecturers & Mean & $\begin{array}{l}\text { Total } \\
\text { frequency }\end{array}$ \\
\hline 1. & Gained initial subject knowledge from studying & 3.45 & 832 \\
\hline 2. & Gained initial subject knowledge from work & 3.21 & 776 \\
\hline 3. & Keep up to date through reading & 3.19 & 773 \\
\hline 4. & $\begin{array}{l}\text { Once employed by college developed subject knowledge } \\
\text { through studying }\end{array}$ & 3.30 & 763 \\
\hline 5. & Developed teaching skills through studies & 3.22 & 761 \\
\hline 6. & Developed teaching skills through reading & 3.16 & 756 \\
\hline 7. & $\begin{array}{l}\text { Once employed at the college developed subject knowledge } \\
\text { through work }\end{array}$ & 3.14 & 745 \\
\hline 8. & Developed assessment skills through studies & 3.17 & 741 \\
\hline 9. & Keep up to date through studies & 3.11 & 734 \\
\hline 10. & Developed assessment skills through experimentation & 3.12 & 726 \\
\hline 11. & Developed assessment skills through reading & 3.01 & 708 \\
\hline 12. & Developed teaching skills through experimentation & 3.02 & 704 \\
\hline 13. & Developed teaching skills through past lecturers & 2.85 & 662 \\
\hline 14. & Developed assessment skills through past lecturers & 2.89 & 660 \\
\hline 15. & Initial subject knowledge from general experience & 2.83 & 649 \\
\hline 16. & Initial subject knowledge from training & 2.83 & 647 \\
\hline 17. & $\begin{array}{l}\text { Once employed at college developed subject knowledge } \\
\text { through general experience }\end{array}$ & 2.83 & 626 \\
\hline 18. & Developed assessment skills through colleagues & 2.67 & 613 \\
\hline 19. & Keep up to date through work-integrated learning & 2.66 & 612 \\
\hline 20. & $\begin{array}{l}\text { Once employed at college developed subject knowledge } \\
\text { through training }\end{array}$ & 2.59 & 590 \\
\hline 21. & Developed teaching skills through colleagues & 2.50 & 583 \\
\hline 22. & $\begin{array}{l}\text { Once employed at college developed subject knowledge } \\
\text { through colleagues }\end{array}$ & 2.50 & 567 \\
\hline 23. & Keep up to date through entrepreneurship & 2.27 & 529 \\
\hline
\end{tabular}

The group "Lecturers who gained their initial subject knowledge from studying" were ranked first with an overall mean score of 3.45. The majority of the TVET lecturers, therefore, seemed to rely on content knowledge gained from initial studies.

"Lecturers who gained initial subject knowledge from working" was ranked second with an overall mean score of 3.21. However, according to the means obtained (see Table 5), a total of 52.2 per cent of lecturers had less than five years' industry experience at the time of the survey. The subject knowledge obtained through working may therefore be insufficient.

"Lecturers who keep up to date through reading" was ranked third with an overall mean of 3.19. "Lecturers who developed their subject content knowledge through studying after being employed by the college" was ranked fourth with an overall mean of 3.3. A large number of lecturers, therefore, developed their content knowledge by furthering their studies after being 
employed by colleges. Items ranked first to fourth relates to subject content knowledge. At TVET colleges, there is therefore a strong focus on subject content knowledge among lecturers.

The group "Lecturers who developed their teaching skills through studying" was ranked fifth with an overall mean of 3.22. A large number of lecturers therefore improved their teaching skills by furthering their studies.

"Lecturers who developed their teaching skills through reading" is ranked sixth with an overall mean score of 3.16. The group "Lecturers who developed their subject knowledge through work once employed by the college" was ranked seventh with an overall mean score of 3.14. In the absence of a formal mentoring and training programme lecturers are mentoring themselves in order to improve their teaching skills and subject knowledge (Van der Bijl 2015, 50, 131; Manyau 2015, 76).

Ranked eighth, with an overall mean score of 3.17, was the group "Lecturers who developed their assessment skills through studying". Ranked ninth was "Lecturers who kept up to date through studies" with an overall mean of 3.11. Ranked tenth, with an overall mean score of 3.12, was "Lecturers who developed their assessment skills by experimenting".

Noteworthy is the position of studying and experience in initial development compared to further professional development once employed in education. While study and gaining experience rate high in initial development, they feature lower in decisions related to further professional development. The position of work integrated learning (WIL) and entrepreneurship at the bottom of the scale, with a mean of 2.50 and 2.27 , respectively is noteworthy. It is through WIL, by being exposed to industry practice, and entrepreneurship, by gaining income from private work that lecturers can keep up to date with existing practice. The placement of WIL and entrepreneurship last in the list of development priorities lecturers indicate the value placed on their own practice. Clearly qualifications and experience are seen as important for gaining employment and further qualifications relatively important for further professional. Continued development of experience is, however, not perceived as important.

\section{IMPLICATIONS OF THE NATIONAL TVET LECTURER SURVEY ON QUALIFICATIONS AND EXPERIENCE IN THE TVET COLLEGE SECTOR}

The position that lecturers hold, both within TVET colleges and the broader economy, requires expertise in at least three domains, namely academic or subject matter knowledge, pedagogy, and workplace qualifications and experience (McBride et al. 2009, 7; Smith and Grace 2014, 204; Lloyd 2008, 175).

While conditions vary greatly across education contexts, vocational systems across the globe have grappled with the same issues that occur in the South African TVET college system 
(Papier 2008. 5).

The TVET college system in United Kingdom exhibits many of the trends regarding governance, certification and professionalism of college staff seen in the South African TVET system. Reform has taken place with frequent reflection and revision of systems and policies. As a result, sufficiently capacitated colleges that earned the confidence of universities received accreditation to offer initial teacher qualifications for college staff (Papier 2008, 11).

In Australia, TVET lecturer qualifications remain a highly contested issue. Lecturers are only required to have a pre-university, certificate-level pedagogical certificate, and possess significantly lower level qualifications than educators in other education sectors (Smith, Hodge and Yasukawa 2015, 419). In Australia, as in South Africa, the issue of lecturer qualifications remains to be answered.

In South Africa a large and significant number of lecturers are in need of either an academic qualification, teaching qualification or workplace qualification. Studies show that many lecturers only have one of the three types of qualifications required (McBride et al. 2009, 7; Manyau 2015, 63-75).

Some universities have addressed the qualification shortage by offering the National Professional Diploma in Education (NPDE) to lecturers in need of a teaching qualification. The qualification was introduced as an in-service programme and offered on a part-time basis (Papier 2008, 9).

In addition to a teacher's qualification, lecturers need a theoretical foundation from which to draw subject specific knowledge. Theoretical wisdom is knowledge wisdom of the first principles and is the most precise form of knowledge. Theoretical knowledge is a higher form of knowledge than practical knowledge because it deals with the first causes and principles of things (Moodie 2002, 250). As theoretical knowledge forms the foundation from which skills training is offered, it is critical that lecturers obtain theoretical qualifications in their field of speciality. The full content of a theoretical qualification cannot be contained in a teacher's qualification. Attempts to combine a teacher's qualification with theoretical knowledge may therefore be futile. Rather, it is recommended that lecturers, in addition to obtaining a teaching qualification, register and complete a theoretical qualification in the field of their speciality. Skills training can only be offered effectively by drawing knowledge gained from a theoretical foundation.

Work-based learning may enable professionals to re-affirm the importance of experiential learning, and reinforce the centrality of ethical and professional practice (Hyland 2010, 168). Lecturers who lack workplace experience and qualifications need to receive skills training and gain access to workplace qualifications such as trade testing. In order for lecturers to receive 
access to trade testing, legislation may be required to open up trade test opportunities and remove mechanisms that block them from qualifying as artisans.

According to Mzabalazo advisory services (South Africa 2014, ii) the existing routes to workplace qualifications, or artisan development consists of multiple routes, many of whom are complex, and do not allow for optimal integration of theoretical, practical and workplace knowledge and experience. There are a number of challenges related to artisan development in South Africa. SETA Bureaucracy, Mzabalazo advisory services (South Africa 2014, ii) explains, frustrates employees and grant disbursement is ineffective and slow. The SETA's, who play an important role in training artisans, ironically, seem to block the training of future artisans by means of bureaucracy. Lecturers may therefore find it very difficult to obtain workplace qualifications.

Lecturers who lack academic qualifications, teaching qualifications or workplace qualifications should not be blocked from entering the TVET college sector. Instead, lecturers who lack qualifications should be informed and supported to improve their qualifications through study loans, bursaries, salary increments and emotional support.

Further research is required regarding the value of lecturers qualifying as artisans in their field of speciality. As TVET colleges are focussed on placing students in the workplace, a workplace qualification will add value to lecturer's understanding of the industry, effectively preparing students for industry and linking theory to practice. The possibility of incorporating workplace skills training to office- and business-related qualifications as it is done in the engineering fields requires further research.

\section{CONCLUSION}

Ideally TVET college lecturers should have an academic qualification, teaching qualification and workplace qualification and experience (Lloyd 2008, 175; McBride et al. 2009, 7; Smith and Grace 2014, 204). The qualification profile of a TVET lecturer is therefore horizontal, covering a large area of knowledge and skills on the same level.

Academic qualifications, associated with subject in the field within which a TVET lecturer work include undergraduate and postgraduate qualifications offered at universities where such qualifications are characteristically broad and formative rather than occupation specific (McBride et al. 2009, 7). A substantial number of lecturers working at TVET colleges lack academic qualifications, and therefore lack subject knowledge needed in lessons. TVET lecturers can supplement their academic knowledge and qualifications by doing the N4 to N6 courses offered by TVET colleges. Alternatively, lecturers who lack academic qualifications may register at universities of technology for a diploma in their field of expertise. 
Teaching qualifications, or qualifications in the field of education often determines how effectively lecturers are able to facilitate the learning of subject knowledge with students (McBride et al. 2009, 7; Redmond 2017, 55). Many TVET lecturers were found to lack teaching qualifications, and may find it difficult to effectively engage students during lessons. An initiative from DHET saw many TVET lecturers completing a NPDE. This initiative need to be strengthened to see more lecturers become professional educators.

Workplace qualifications and experience prepare individuals for specific types of work, with a strong focus on practical applications (McBride et al. 2009, 7). Many lecturers were found to lack workplace experience and qualifications. Lecturers who lack workplace qualifications may therefore not understand the importance of preparing students for working in industry. Furthermore, these lecturers may lack the experience from industry needed to incorporate real life situations into lessons.

TVET colleges play an important role in providing a skilled workforce to countries internationally. As a developing country, South Africa has to ensure that TVET lecturers are fully qualified and competent to fulfil their role in preparing a future workforce that will contribute meaningfully to the economy. Existing research indicates deficiencies in South African TVET lecturer qualifications (McBride et al. 2009; Manyau 2015).

\section{REFERENCES}

Arfo, E. B. 2015. A comparative analysis of technical and vocational education and training policy in selected African countries. Durban: UKZN. PhD Thesis.

Bialobrzeska, M. and S. M. Allais. 2005. Being a vocational educator A guide for lecturers in FET colleges. Braamfontein: SAIDE.

Blom, R. 2016. Curriculum framework for the Advanced Diploma in Technical and Vocational Teaching. Undertaken on behalf of the Department of Higher Education and Training (DHET); and kindly funded by the Education Training and Development Practices Sector Education and Training Authority (ETDP SETA). Unpublished report.

Guthrie, H. 2010. Professional development in the vocational education and training workforce. Adelaide: National centre for vocational education research.

Hyland, T. 2010. Professionalism, ethics and work based learning. British Journal of Educational Studies 44(2): 168-180.

Lloyd, C. 2008. Recruiting for fitness: Qualifications and the challenges of an employer led system. Journal for Education and Work 21(3): 175-195.

Manyau, T. 2015. Assessing skills development management for lecturers in technical vocational education and training colleges in North-West province. Mafikeng: NWU.

McBride, T., J. Papier and S. Needham. 2009. FET college lecturers in the Western Cape. Cape Town: UWC.

Mmako, M. and C. Schultz. 2016. An employee engagement framework for Technical Vocational Education and Training colleges in South Africa. South African Journal of Higher Education 30(2): 143-1673.

Moodie, G. 2002. Identifying vocational education and training. Journal of Vocational Education and 
Training 54(2): 249-266.

Papier, J. 2008. Report on the training of FET college lecturers in South Africa, England, and other international contexts. Cape Town: UWC.

Pietersen, J. and K. Maree. 2014. Standardisation of a questionnaire. In First steps in research, ed. K. Maree, 215-222. Pretoria: Van Schaik.

Redmond, P. 2017. VET practitioner's perceptions of VET higher education qualifications. International Journal of Education Research 15(1): 55-70.

Sheahan, J. 1982. A view of the professional standing of a college of education lecturer. The Vocational Aspect of Education 34(87): 23-27.

South Africa. 2008. Draft National Policy Framework for Lecturer Qualifications in FET Colleges in South Africa. Pretoria. Government Printer.

South Africa. 2010. Document for discussion: Challenges facing the FET college subsystem, FET Round Table towards finding resolutions in partnership with stakeholders, 9 April, Government Printer, Pretoria.

South Africa. 2012. Green paper on post-school education and training. Pretoria: Government printer. $100 \mathrm{p}$.

South Africa. 2013. Policy on professional qualifications for lecturers in technical and vocational education and training. (Notice 410). Government gazette, 36554: 2, 11 June.

South Africa. 2014. Mzabalazo advisory services. Expenditure performance review of the national artisan development programme. Pretoria: Government printer.

Smith, E. and L. Grace. 2014. Vocational educator's qualifications: A pedagogical poor realisation? International Journal of Training Research 9(3): 204-217.

Smith, E., S. Hodge and K. Yasukawa. 2015. VET teacher education in Australian universities: Who are the students and what are their views about their courses? Research in Post Compulsory Education 20(4): 419-433.

Van der Bijl, A. 2015. Mentoring and the development of educators in South African technical and vocational education. Stellenbosch: US, MEd.

Van Der Bijl, A. and M. Lawrence. 2016. The theory and practice of vocational teaching. In Learn to teach: A handbook for initial teacher education, ed. C. Okeke, J. Abongdia, Adu E. Olusola, M. vn Wyk and C. Wolhuter. Cape Town: Oxford University Press.

Van der Bijl, A. and V. Taylor. 2016. Nature and dynamics of industry-based workplace learning for South African TVET lecturers. Industry \& Higher Education 30(2): April.

Wedekind, V. 2016. Technical and Vocational Education and Training (TVET) reform in South Africa: Implications for college lecturers, context, background. SAQA Bulletin 15(1): 1-29. 